\title{
Access to Quality Health Services for All South Africans through the National Health Insurance Scheme: Lessons from Singapore
}

\author{
Lufuno Nevondwe \\ K.O. Odeku
}

Faculty of Management and Law, School of Law, University of Limpopo, South Africa

\section{Doi:10.5901/mjss.2014.v5n23p2722}

\section{Abstract}

The South African health system both in the public and private sectors is fraught with many challenges which render the system unsustainable, costly, hospi-centric, and destructive. In order to curb this loop hole in the health sector, South Africa introduced the National Health Insurance (NHI) that is aimed at providing universal coverage of health care. The objectives of $\mathrm{NHI}$ is to provide improved access to quality health services for all South Africans irrespective of whether they are employed or not; to pool risks and funds so that equity and social solidarity will be achieved through the creation of a single fund, to procure services on behalf of the entire population and efficiently mobilize and control key financial resources and to strengthen the under-resourced and strained public sector so as to improve health systems performance. This paper evaluates the Reconstruction and Development Programme (RDP), Growth, Employment and Redistribution (GER), New Growth Path (NGP) and National Development Plan (NDP) policies to determine the challenges and positive aspects of these policies that can be used for the successful implementation of the NHI. The paper further draws lessons from Singapore that has already implemented the NHI and argues that South Africa can learn a lot from these countries experiences. It is concluded that each of the countries provide inspiring positive lessons and also show areas of challenges from which South Africa can draw some lessons

Keywords: National Health Insurance Scheme. Health care services. Insurance. Constitution. South Africa

\section{Introduction}

The key questions surrounding health care systems around the world include among others; (a) how to raise revenues to pay for health care,(b) how to pool risks and resources, (c) how to organize, deliver health care in the most efficient and cost effective manner. Whether the strategies adopted rely on public sources like taxes and social insurance, or private sources like private insurance and out of-pocket payment, will have a profound impact on health care costs, quality and access (Berman et al. 2009).

In making the choice, technical efficiency is an important, but not the only consideration. Most health care systems in western industrialised countries assume a high degree of responsibility for personal health care because they are driven by values which lean heavily towards notions of equity, fairness and solidarity (Kim 2005). With the notable exception of the United States, the entire Organisation for Economic Cooperation and Development (OECD) countries (including Japan and South Korea) have opted for publicly financed health care systems that provide universal coverage (Tamiya et al. 2011).

Singapore has one of the world's renowned health care system that is underlined by a successful National Health Insurance (NHI) scheme (Okma et al. 2010). The NHI in Singapore is operationalized by a model that seeks to answer the questions raised above on providing access to health care for all citizens ( Lim 2012). South Africa is in the process of adopting its own model of $\mathrm{NHI}$ that is underpinned by various national economic growth policies implemented since 1994 ( Mayosi et al. 2009). By introducing the NHI the government seems to be taking a different direction from the policy position of the past two decades (Nevondwe and Odeku 2014). South Africa can learn from the progressive lessons and challenges experienced by Singapore to implement and operationalize its $\mathrm{NHI}$. In deriving the lessons, part one of the discussion will look at the implementation of the $\mathrm{NHI}$ in Singapore using the 3M model. The second part will discuss the South African position regarding the NHI in the context of economic growth policies adopted since 1994. The third and final part of the paper will look at the lessons that can be drawn from the Singaporean system and the recommendations that can aid South Africa to implement a successful health system that will enable citizens to access quality health care. 


\section{Objective}

The objective of the study is to evaluate the implementation of $\mathrm{NHI}$ in Singapore and determine the lessons which South Africa can learn as it is in the process of implementing $\mathrm{NHI}$. The study also determines whether the success and shortcomings of implementation of Reconstruction and Development Programme (RDP), Growth, Employment and Redistribution (GEAR) and the New Growth Path (NGP) policies would be in any how a guiding tool to successfully implement NHI. This will be in light of the recently introduced National Developmental Plan (NDP) which is the new economic growth path that has been adopted by South Africa to direct national development.

\section{Motivation and Significance of the Study}

The study contributes significantly to knowledge and jurisprudence that exist regarding reforming the health care system in South Africa and foreign countries in order to bring about equitable access to essential services, administrative efficiency, increased revenue and quality improvements. The study will benefit Health Practitioners, Department of Health, Medical Students, Non-Government Organisations and countries that are yet to implement NHI.

\section{Methodology}

The research methodology used in this study is qualitative as opposed to quantitative. This research is library based and reliance is on library materials such as textbooks, reports, legislations, regulations and articles. Consequently, a combination of comparative and historical methods, based on jurisprudential analysis was employed. A comparative method was applied to find solutions to the existing shortcomings of $\mathrm{NHI}$ in South Africa. The study established the development of health care jurisprudence and social justice, and proposed solutions or amendments to the existing policies, based on practical or empirical and historical facts. Concepts were analysed and arguments based on discourse analysis were developed.

\section{National Health Insurance Implementation in Singapore}

Singapore's experience offers valuable lessons for South Africa's health care reform system. In 1980s, the Singapore government reexamined the principles of the role of the state in health care financing and provision, and concluded that the British style for the National Health Service was neither a viable nor a sustainable option (Lim 2005). The government of Singapore decided that while it would continue to subsidies health care (along with other important social areas like housing and education) to bring prices down to an affordable level, the people would have to share in the costs of the services they consume (Kim 2005).

The state of health in Singapore is internationally regarded and consistently ranked by the World Health Organisation to be among the world's best (WHO 2000). Approximately 70 to $80 \%$ of Singaporeans prefer to use the public health care because the care is good and subsidies are available (Shiou-Liang et al 2014). One of the reasons behind the success of Singapore's government achieving these health outcomes is a result of a comprehensive healthcare delivery and financing system ( Cheah 2000). There has been a "creative policy mix of government intervention and market mechanisms" that has seen the success in access to health care in Singapore (Wu and Ramesh 2014). The system is built on the major principles of, promoting good health, reducing illness, access to good and affordable healthcare and pursuing medical excellence (von Eiff 2002). This system also ensures that all Singaporeans have access to affordable basic healthcare, basic medical services at public hospitals and polyclinics are heavily subsidized by the government (Maarse et al. 2010).

\section{Singapore Health Care System in a Nutshell}

The system of healthcare in Singapore is based on the "3M system". Under the "3M framework" individuals are encouraged to take responsibility for their own health by saving for medical expenses. The "3M system" has its origins from the following tiers of protection, the Medisave (1984), Medishield (1990) and Medifund (1993) (MoH 2011). These tiers of protection form the centerpiece of Singapore's health care financing system and were therefore premised on the philosophy of shared responsibility, and the economic principle that health care services should not be supplied freely on demand without reference to price. According to Callick the government subsidies of up to 80 percent of the total bill in acute public hospital wards, which all Singaporeans can access. The first tier of protection is provided by Medisave, 
which is a compulsory individual medical savings account scheme which allows practically all Singaporeans to pay for their share of medical treatment without financial difficulty (Callick 2008). Working Singaporeans and their employers contribute a part of their monthly wages into the account to save for their future medical needs and this is portable across jobs and after retirement (Castro 2009). According to the Singapore Ministry of Health in December 2008, the average Singaporean had ten thousand US dollars in his/her Medisave account. This is sufficient to pay for about 10-12 subsidized acute hospitalization episodes (Castro 2009).

The second level of protection is provided by MediShield, a low cost catastrophic medical insurance scheme. According to Loh (2013), this allows Singaporeans to effectively risk-pool the financial risks of major illnesses. Individual responsibility for one's healthcare needs is promoted through the features of deductibles and co-payment in MediShield. Severe disability insurance, ElderShield is also available for subscription by Singaporeans to risk-pool against the financial risks of suffering a severe disability. Many middle and higher income Singaporeans have also supplemented their basic coverage with integrated private insurance policies ("Integrated Shield plans") for treatment in the private sector. Singaporeans must subscribe to the basic MediShield product before they can purchase the add-on private Integrated Shield Plans. This industry structure preserves the national risk pool and guards against 'cherry picking' of healthy lives by private insurers. Similarly, "ElderShield Supplements" allow policyholders to enhance the disability benefits coverage offered by the basic ElderShield product (MoH 2013).

According to Callickthe Singapore health system has put in place the "3M" framework. Medisave, which covers about 85 percent of all Singaporeans, is a component of a mandatory pension program (Callick 2008). Employees typically pay 20 percent of their wages into the Central Provident Fund (CPF), while employers pay 13 percent (since 1992, the self-employed have also participated). At the beginning of 2007, CPF had over $\$ 1$ billion in surpluses (Callick 2008).

According to Shortt (2002) in Singapore's system, the primary role of government is to encourage people to save in order to meet medical expenses they do not expect. Medisave accounts can be used to pay directly for hospital expenses incurred by an individual or his immediate family. Limits are in place on the extent of Medisave funds that can be used for daily hospital charges, physicians fees, and surgical fees. The idea is to cover fully the bills of most patients in statesubsidized public hospitals. Beyond that, individuals dip into their own pockets or use benefits from insurance plans (see more on this below). Medisave can also be used for expensive outpatient treatments such as chemotherapy, renal dialysis, or HIV drugs (Shortt 2002).

Medishield, the second part of the program, is a national insurance plan that covers the higher cost of serious illness or accident victims, which in Singapore's system is described as "catastrophic." Singaporeans can choose Medishield or several private alternatives, some offered by firms listed on the Singaporean stock exchange. Premiums for the insurance plans, including Medishield, can be paid using Medisave accounts (Callick 2008).

Medifund, the third part, was established by the government for the roughly 10 percent of Singaporeans who do not have the means to pay for their medical needs, despite the government's subsidy of hospital and outpatient costs (Callick 2008). The fund was set up in 1993 with $\$ 150$ million and the budget surplus provides additional contributions since then. Only interest income, not capital, may be disbursed (Callick 2008). Finally, there is Eldershield, an addition to the $3 \mathrm{M}$ structure that offers private insurance for disability as a result of old age. It pays a monthly cash allowance to those unable to perform three or more basic activities of daily living (Callick 2008).

Nearly all Singaporeans contribute directly toward each treatment, including prescription drugs, through patient copayments of 20 percent for amounts above deductible levels. The money to meet deductibles and co-payments can come out of a person's Medisave account (Callick 2008).

According to Callick since 2002 the public healthcare facilities in Singapore have been clustered into two integrated networks, each government-owned and managed as nonprofits. The National Healthcare Group (NHG) on the western side of the city-state, and Singapore Health Services (Sing Health) on the eastern side (Callick 2008). Each provides a full range of services, running public hospitals and specialty centers as private companies. The Health Ministry states that these clusters "provide cooperation amongst the institutions within the cluster, foster vertical integration of services, and enhance synergy and economies of scale. The friendly competition between the two clusters spurs them to innovate and improve the quality of care while ensuring that medical costs remain affordable." (Callick 2008).

Each of the networks also benchmarks against international standards and publishes exhaustive performance figures. In its 2007 report, NHG states that its vision is "adding years of healthy life." According to the report the goal, "departs from merely healing the sick to the more difficult but infinitely more rewarding task of preventing illness and preserving health and quality of life." (Callick 2008). Meanwhile, 80 percent of primary healthcare needs are met by private general practitioners and 20 percent by public outpatient "polyclinics" of hospitals, chiefly those run by the two clusters, NHG and SingHealth. Within the private general practitioner sector, a significant proportion of patients of about 
12 percent consult traditional Chinese practitioners. (Callick 2008).

Phua (1997), describes the crucial factors that enabled the country to create its remarkably successful health system as: a dynamic economy (with 7.5 percent GDP growth in 2007 and an average income per person of about $\$ 34,000$, or three-quarters that of the United States), strong family ties and social support systems, a high propensity to save and invest, a rapidly aging and affluent population, and an absence of socialized models of social security, social insurance, or healthcare. (Phua 1997). Phua lists five core prerequisites for countries that may want to emulate Singapore's system: a willingness and ability to save; high participation in formal employment; effective payroll collection with efficient fund management and claims processing; a well-developed information system with strong security and accounting controls; and effective public education in the proper use of medical accounts. (Phua 1997).

Phua observes that most people within the private-public mix lean toward the private system for primary care and the public system for hospital care. There are 13 public-sector specialty centers and hospitals in Singapore and 16 private-sector hospitals. But 74 percent of the beds are within the public sector (Phua 1997). The government has also introduced low-cost community hospitals for intermediate healthcare for the convalescent and aged.

The most cardinal question is why does Singapore's system work? Phua cites these principles "the creation of incentives for responsible behavior and the efficient delivery of services; the discouragement of overconsumption through cost-sharing; the regulation of hospital beds, doctors, and the use of high-cost medical technology; the promotion of personal responsibility; targeted government subsidies; and the injection of competition through a mix of public- and private-sector providers." (Phua 1997). According to Phua Medical savings are now being accumulated to ensure that the Singaporean society of the future will be able to look after its own health needs even with a steady rise in the population of elderly people (Phua 1997).

Phua opines that room remains for further evaluation of clinical quality and outcomes as the system continues to evolve. Increased investment in health facilities is encouraging a broadening of the market. According to Phua more than 400,000 patients traveled to Singapore for healthcare in 2006. While 3M was designed to curb overconsumption rather than achieve a particular public-private mix, the result of the system has been to moderate the government's share of total health spending (Phua 1997). The lesson here is that an efficient healthcare system will naturally come to rely on consumer, rather than government, decision-making.

According to Callick (2008) Singapore's Health Minister, Khaw Boon Wan encourages insurers to come up with more innovative policies. More in particular, Callick quotes the Health Minister, Khaw Boon Wan as saying: "Give doctors and hospitals the incentive to focus on the health outcomes of your policyholders. Try piloting pay-for-performance measures that reward doctors based on the health of patients they care for, not the number of procedures performed."(Callick 2008).

According to Callick (2008) the World Bank, in a paper assessing Singapore's health system, provides that the results of $3 \mathrm{M}$, with its supplementary programs to protect the poor and to address potential market failures in health financing, have been impressive, with excellent health outcomes, low costs, full consumer choice of providers and quality of care (Callick 2008). Accordingly the World Bank provides that the Medisavea key component of the system could be introduced in countries without national insurance programs or well-developed private insurance, by requiring all employers and employees to set up accounts along the lines of Singapore's program (Callick 2008).

In countries such as Canada and Britain which have national insurance programs funded primarily by general tax revenue, Medical Savings Accounts (MSAs) could be introduced by directly allocating a portion of existing tax revenue spent on healthcare to individuals to set up MSAs. Such governments could then progressively reduce general taxes and replace them with Singaporean-style payroll deductions allocated to MSAs (Callick 2008).

However South Africa can also learn some valuable lessons from other countries. The United States of America (USA) through President, Barack Obama's reform plans involved the introduction of a national health system in the USA (Oberlander 2010). The system was introduced through the United States National Health Care Act and the Expanded and Improved Medicare for All Act ( Manchikanti and Hirsch 2009). This caused a heated debate among the Americans, as some felt this was bent on Government takeover of private healthcare among other concerns (Haeder 2012). In Britain, on the other hand, the National Health Service (NHS) has been implemented since the 1940's and the British have nothing but praise for this system ( Hacker 1998). The Britons claim that through the NHS, 1 million people gain access to healthcare every 36 hours (Goodman 2005). In response to an attack against Obama, Prime Minister, Gordon Brown added his voice to a twitter campaign saying "the NHS often makes the difference between pain and comfort, despair and home, life and death." 


\section{South Africa Health Care in a Nutshell}

In South Africa the concept of $\mathrm{NHI}$ is being considered and there are many lessons to be learnt from Singapore. Currently South Africa has a two tier health care financing system being the private health care and public health care (Coovadia et al. 2009). Private health care caters for those who are economically strong and is financed mainly through medical aid schemes. The medical aid schemes are accessible to those employed in the private and public sector and usually subsidized by employers (McIntyre et al. 2003). The unemployed and those in the lower economic strata rely on the health services provided in public hospitals and financed through the fiscus (Seekings 2013). The system maintains access to health care based on one's socioeconomic status. This perpetuates inequalities in the health care system. This state of affairs continues to exist because of the economic growth paths the country has followed since 1994 when it attained freedom. From 1994, there has been the Reconstruction and Development Program (RDP); Growth, Employment and Redistribution (GEAR); New Growth Path (NGP) and the recently introduced National Development Plan (NDP). The economic growth pattern has an impact on how a country finances its heath care system as seen in the discussion above on Singapore.

\section{The NHI Framework}

South Africa adopted a green paper on NHI. The policy seeks to address the historical inequalities in access to health care that have continued 20 years after the country attained democracy (Wax 2013). Access to health care is still based on the socioeconomic status of individuals. According to the Council for Medical Schemes, only $16.2 \%$ of the population can access medical aide schemes (CMS 2009) and this gives them an option of service providers in the private sector whilst the rest of the population is condemned to an under resourced public health care. Under this back drop the NHI green paper was adopted in 2011.

The NHI has the following objectives

a. To provide improved access to quality health services for all South Africans irrespective of whether they are employed or not.

b. To pool risks and funds so that equity and social solidarity will be achieved through the creation of a single fund.

c. To procure services on behalf of the entire population and efficiently mobilize the control of key financial resources. This will obviate the weak purchasing power that has been demonstrated to have been a major limitation of some of the medical schemes resulting in spiraling costs.

d. To strengthen the under-resourced and strained public sector so as to improve health systems performance

In order to meet the objectives, focus will be placed on Primary Health Care (PHC). Under PHC, there will be community outreach projects that will provide health service through District Health Care Services (NHI Green Paper 2011). Three streams of services will be provided under the PHC being

a. District-based clinical specialist support teams supporting delivery of priority health care programmes at a district

b. School based Primary Health Care Services

c. Municipal Ward-based Primary Health Care Agents

To cater for the population that uses private providers for their health care needs, PHC will be delivered through accredited private providers operating within a District (NHI Green Paper 2011). To access the services, there will be healthcare benefits packages for primary health care, district hospital services, regional hospital services and tertiary services (NHI Green Paper 2011). The funding mechanism of the NHI will be achieved through a prepayment health financing mechanism that will be pooled from the fiscus, employers and individuals NHI Green Paper 2011). A funding model that will be able to sustain the high costs involved in the initial stages and sustain the long term objectives of the $\mathrm{NHI}$ is being developed. The South African Revenue Services (SARS) will collect all the revenue and the funding for personal health care will flow through the National Health Insurance Fund. Contributions to the NHI will be mandatory for all citizens and permanent residence permit holders although one will remain with an option to continue with voluntary private medical schemes (NHI Green Paper 2011). Nevondwe and Odeku argue that funding contributions of the NHI would be linked to an individual's ability to pay and benefits from health services would be in line with an individuals need for care Nevondwe and Odeku 2014). Funding the NHI will be the greatest challenge in implementing the scheme. To put this into perspective, understanding the economic models that have been used by South Africa since 1994 are imperative. 


\subsection{Reconstruction and Development Program (RDP)}

Prior to South Africa's first democratic elections in April 1994, the ANC agreed in principle to adopt COSATU's Reconstruction and Development Programme (RDP) - a programme that contained elements of social security in return for COSATU's support in the elections (Lodge, 1999). Thus the RDP formed the basis of the ANC's election manifesto. The RDP was an ideological reference point to confirm the continuity in the political-historical between the Freedom Charter and the realities of post-apartheid South Africa (RDP 2010).

The RDP was originated to tie the newly elected ANC government to a labour-driven development programme. As a "growth through redistribution" policy, the RDP envisioned as a first priority: beginning to meet the basic needs of people: jobs, land, housing, water, electricity, telecommunications, transport, a clean and healthy environment, nutrition, health care, and social welfare" (RDP White paper 1994).

The RDP soon became the paradigm within which all development policies were to be discussed - an extended wish list in which the homeless, the landless, workers, and even international bankers could take equal comfort (Visser 2004). From 1994 to 1996, the RDP became ostensibly the guiding document of the Government of National Unity, located in an RDP Office within the then President Mandela's Office, under the immediate authority of Minister without Portfolio Jay Naidoo - former General Secretary of COSATU. The RDP policy was one of the most important policies and the pace of service delivery was admirable since houses were built for the poor. Better sanitation was provided to the people (Aldelzadeh 1996).

In terms of social security, the RDP achieved some remarkable results. In line with the "new" Constitution's provisions, all citizens have the right of access to social security in terms of Section 27 (Mclntyre and Gilson 2002). The government established a very extensive welfare system, catering for the aged, disabled, children in need, foster parents and many others too poor to meet their basic social requirements. For instance, free health care services were provided in public clinics (Aldelzadeh 1996).

On the other hand, the RDP had some short falls. The government lacked the capacity to implement the policy. RDP staff lacked sufficient implementation skills thus, huge backlogs in providing access to basic services, as defined in the RDP white paper occurred. The RDP did not spell out a detailed programme for attaining its main aims. It was too broadly formulated and ended up as a wish list for too many people (Aldelzadeh 1996).

It is, therefore, not surprising that the RDP was phased out and replaced by Growth, Employment and Redistribution (GEAR) in 1996. It became clear that the country's economic and fiscal difficulties would impede the realization of the RDP's goals. Although the new government hoped for economic growth rates of 4-6\% per annum, the actual growth rate was only slightly above the natural rate of population growth of about $2.5 \%$ (Visser 2004). The government could not mobilise sufficient funds to meet the RDP's objectives without redirecting allocations from the mainstream government departments. In a climate of resource scarcity, competition among ministers was intense and the prospect of having their budgets appropriated by the RDP administration was strongly resisted (Visser 2004).

In fact, most of the funding for the RDP's programmes had come not from the South African government but from international donors, and it was generally project based. As economic considerations began to dominate government policy in the latter half of the 1990s, the lofty social commitments of the RDP were given less prominence than the need for rapid economic growth (Midgley 2001).

The death blow to the RDP was dealt in a White Paper on Reconstruction and Development published in November 1994. The White Paper departed significantly from the original RDP document. It introduced fiscal prudence not as a means of attaining RDP objectives, but as an added goal. The notion of redistribution was dropped, as the government's major role in the economy was reduced to the task of managing the transformation. Given the ANC's commitment to fiscal discipline and macroeconomic balance, no fiscal "space" was available for properly implementing the RDP and for the redistributive implications of its poverty-alleviation programme and its emphasis on meeting basic needs (Terreblanche 2003).

According to Visser (2004), "the final nail was driven into the coffin of the RDP when the new ANC government encountered its first major currency crisis, starting in February 1996 when the value of the rand plummeted by more than $25 \%$. In order to calm domestic capital and foreign currency markets, the government embraced a conservative macroeconomic strategy, GEAR." Protagonists and pundits have persistently been criticizing the ANC government for its change in economic policy (Aldelzadeh 1996).

\subsection{National Growth Path}

The ministry of the RDP was abolished in March 1996 and the office of the RDP was transferred to the office of the then 
Deputy-President, Thabo Mbeki. In contrast to the RDP, GEAR was not the product of consultation with COSATU and the SACP, and this generated considerable internal disagreement within the tripartite alliance (Kotzé 2000). This policy sustained the South African economy for some time before it was substituted by the New Growth Path (NGP) introduced by the Minister of Economic Development, Mr. Patel and approved by the cabinet on 24 November 2010. One of the key objectives of South African Government as articulated in the NGP is to invest in social capital and public services. By introducing the NHI Government will not only address the health care disparities facing South Africa but, the Government will also be in compliance with its mandate of job creation.

There are more lessons to be learned from the RDP policy for $\mathrm{NHI}$ to be successful. The cost of the $\mathrm{NHI}$ is too high and South Africa has a lot of problems to address ranging from poor education, housing, sufficient water and lack of tarred roads. A careful analysis of the best model for the $\mathrm{NHI}$ would be a good option rather than a model which will put financial burden on the government.

This Bill still has to be subjected to public debate and would also be shaped by Members of Parliament to represent the aspirations of the people. The Bill provides for an independent entity, the Office of Health Standards Compliance that is aimed at halting the deterioration in the quality of the health care by providing a legal framework to ensure compliance in preparation for the roll out of the NHI from 2012 (Davis 2010). The regulatory body would ensure that all facilities complied with set requirements and that without accreditation; they would not fall under the NHI (Davis 2010).

The NHI would strengthen the six basic principles which need improvement by the National Department of Health which includes, inter alia, the following, safety hygiene, queues, drugs stocks, staff ethics and motivation and improved accountability (Davis 2010).

The phasing in of $\mathrm{NHI}$ will require substantial reforms to address imbalances across the public and private sectors and expand health professional training. The financial and organisational implications of these reforms are being jointly addressed by the Department of Health and the Treasury (Gordhan 2011).

Proposals are under review for $\mathrm{NHI}$ insurance system, as part of the broader restructuring and enhancement of health services. There will be substantial cost implications. The government will consider and consult on options for meeting the funding requirements, including a payroll tax (payable by employers), an increase in the VAT rate and a surcharge on individuals' taxable income. The fiscal and financial implications of health system reform, and alternative revenue sources, will be examined in the year ahead (Gordhan 2011).

Having the RDP and GEAR failing to meet the objectives of the South African government to create a better life for all, the government released yet another new economic policy, the National Growth Path (NGP) on 23 November 2010. The aim of the NGP is to increase economic growth to sustainable rates of between $6 \%$ and $7 \%$ per year in order to create five million jobs by 2020 , thereby reducing the unemployment rate to $15 \%$. The idea behind NGP is noble, but the question that perhaps needs to be determined is whether the target of NGP is indeed feasible (Van Aardt et al. 2011). In order to answer this question, according to Van Aardt, Ligthelm and Van Tonderthe following needs to be looked into:

- whether other countries were able to achieve similar targets;

- establishing whether higher economic growth will automatically translate into higher job creation;

- whether the sectors identified in the NGP (utilities, transport and communication, construction, agriculture, mining, manufacturing) are labour absorptive (high or low employment elasticity); and

- the number of businesses that need to be created to in turn create the five million jobs.

Research shows that it is possible for a country to achieve the stated targets of NGP, however the research also revealed that compared to other countries with similar features, South Africa performed poorly on both job creation and economic growth fronts between 1994 and 2009?(Van Aardt et al. 2011). In addition, it became clear that the conditions created by government do not favour the achievement of the stated targets. For instance, for higher economic growth to translate into increasing job creation, economic growth should ideally be of a labour absorptive nature. However, analysis regarding the relationship between Gross Value Added (GVA) and employment per sector showed that employment growth was negative in five of the 10 years between 2001 and 2010, whilst only one year of negative economic growth occurred?(Van Aardt et al. 2011). Moreover, analyses revealed that a very weak relationship prevails between GVA and employment creation in most of the sectors. This implies that factors other than economic growth have a major impact on both job creation and job destruction in South Africa?(Van Aardt et al. 2011).

In order to achieve the target of NGP, it is clear that the needs to be more businesses that will create such jobs. However, van Tonder, van Aardt and Ligthelm found that it is more difficult, time-consuming and expensive to establish businesses in South Africa compared to countries with, for example, low unemployment rates. As such, the current number of businesses needed to create the five million jobs may have to increase by between $50 \%$ and $70 \%$ up to year 
2020 (Van Aardt et al. 2011).

Critics of the NGP programme view the government's target of five million jobs by 2020 to be unrealistic, especially considering the statistical data. It is submitted that in order to achieve five million jobs by 2020 , South Africa would have needed a growth rate of $9 \%$ in 2011, and a constant growth rate of $7.6 \%$ until the year 2020 . According to the International Monetary Fund, South Africa's Gross Domestic Product is projected to stay under 4\% until 2016, highlighting the unrealistic optimism of the government's target (PASA 2012).

\subsection{National Developmental Plan}

The government recently introduced another programme, the National Development Plan (NDP) which aims to eliminate poverty and reduce inequality by 2030 . According to the plan, South Africa can realise these goals by drawing on the energies of its people, growing an inclusive economy, building capabilities, enhancing the capacity of the state, and promoting leadership and partnerships throughout society (NDP). The NDP and its proposals will need to be implemented in the next 17 years.

President Jacob Zuma appointed the National Planning Commission in May 2010 to draft a vision and national development plan. The Commission is an advisory body consisting of 26 people drawn largely from outside government, chosen for their expertise in key areas (NDP:15). The Commission's Diagnostic Report, released in June 2011, set out South Africa's achievements and shortcomings since 1994. It identified a failure to implement policies and an absence of broad partnerships as the main reasons for slow progress, and set out nine primary challenges:

- Too few people work

- The quality of school education for black people is poor

- Infrastructure is poorly located, inadequate and under-maintained

- Spatial divides hobble inclusive development

- The economy is unsustainably resource intensive

- The public health system cannot meet demand or sustain quality

- Public services are uneven and often of poor quality

- Corruption levels are high

- South Africa remains a divided society.

Is South Africa setting high targets with these policies which arguably are set for failure? With the RDP and GEAR failing to meet the objectives of the South African government to create a better life for all, and with the NDP in its infancy, the question that now remains is whether NHI is also a high target programme for South Africa (Botha 2014). All these programmers show commitment by the South African government to improve the lives of South African. Whether NHI would fail to meet its objectives remains to be seen but what is certain is that South Africa has the potential and capacity to eliminate poverty and reduce inequality and this objective we opine that it can be achieved through job creation. According to Van den Heever, "the ANC is proposing to spend much more money on health care although the amount that South Africa spend compares favorably to other countries with similar gross national incomes (GNIs) per person that are closest to ours" (Du Preez 2010).

\section{Conclusion}

It is evident that the lessons from Singapore offer South Africa valuable lessons to successfully implement NHI. Whilst these lessons are valuable, South Africa has its own distinctive history based on apartheid, which created great inequalities along racial lines in various sectors of both social and economic life, including access to health care. It is against this background that it would not be prudent to adopt the exact model used in foreign countries to implement $\mathrm{NHI}$ in South Africa. South Africa has to embark on a continuous research and assessment of whether the model selected to implement $\mathrm{NHI}$ in South Africa is sustainable taking into account both the social and economic challenges that exist in South Africa.

\section{Recommendations}

The introduction of $\mathrm{NHI}$ in South Africa should be welcomed despite its shortcomings. The $\mathrm{NHI}$ recognizes the right to have access to health care which is one of the fundamental rights in the Constitution. The promotion of the right to have access to health through NHI can arguably be also be the promotion of the right to human dignity as embodied also in the 
Constitution. NHI is a good policy and it is evident that it is not only in South Africa that the health system needs to be reformed, a number of countries have already reformed their health systems to bring about equity in access for needed services, administrative efficiency, increased revenue and quality improvements.

\section{References}

Aldelzadeh A 1996. From the RDP to GEAR: The Gradual Embracing of Neo-Liberalism In Economic Policy" Transformation. From http://archive.lib.msu.edu/DMC/African\%20Journals/pdfs/transformation/tran031/tran031006.pdf. (Retrieved on 11 January, 2014).

Berman P, ArellanesL, Henderson P, Magnoli A, 2009. Healthcare Financing in Eight Latin American Countries and Caribbean Nations: The First Regional National Health Accounts Network. From http://www.who.int/nha (Retrieved on 15 April 2011).

Botha J 2014. Measuring economic transformation: Tracking the progress of an elusive South African dream. From http://mobile.wiredspace.wits.ac.za/handle/10539/15289. (Retrieved on 16 January, 2014).

Callick R 2008. The City- State of Singapore May Have a Fix for Americans Healthcare Woes. From http://american.com/archive/2008 (Retrieved on 14 April 2011).

Castro JM 2009. Health Care in Singapore. From http://www.expatforum.com/articles. (Retrieved on April 2011).

Cheah J 2000. Development and implementation of a clinical pathway programme in an acute care general hospital in Singapore. International Journal Quality Health Care. 12 (5): 403-412.

Coovadia H, Jewkes R, Barron P, Sanders D, McIntyre D 2009. The health and health system of South Africa: historical roots of current public health challenges. The Lancet, 374(9692): 817-834.

Davis G 2010. Ombud for Health Services. From http://www.highbeam.com/doc/1G1-242964784.html. (Retrieved on 29 July 2013).

Du Preez L 2010. NHI won't cure the ills that plague our healthcare system, Personal Finance. From thttp://www.iol.co.za/business /personal-finance/nhi-won-t-cure-the-ills-that-plague-our-healthcare-system-1.998807. (Retrieved on 24 July 2013).

Goodman JC 2005. Health care in a free society. From http://object.cato.org/sites/cato.org/files/pubs/pdf/pa532.pdf. (Retrieved on 15 March, 2014).

Gordhan P 2011. Budget Speech 2011. From http://www.treasury.gov.za/documents/national\%20budget/2011/speech/speech2011.pdf. Retrieved on 23 March 2012).

Hacker JS 1998. The historical logic of national health insurance: Structure and sequence in the development of British, Canadian, and US medical policy. Studies in American Political Development, 12(1): 57-130.

Haeder SF 2012. Beyond Path Dependence: Explaining Healthcare Reform and Its Consequences. Policy Studies Journal. 40:65-86.

Kim L 2005. Transforming Singapore Health Care: Public-Private Partnership. From www.annals.edu.sg/pdf. (Retrieved on 21 June, 2013).

Kotzé D 2000. The Political Economy of Development in South Africa. African Security Review , 9(3): 59-72.

Lim MK 2005. Transforming Singapore health care: public-private partnership. From http://workspace.unpan.org/sites/internet /Documents/UNPAN92985.pdf. (Retrieved on 5 September, 2014).

Lim S 2012. democracy and public health: A multi-part approach utilizing quantitative analysis of international datasets with qualitative analyses of South Korea and Singapore. From http://open.bu.edu/handle/2144/3812. (Retrieved on 15 September, 2014).

Lodge T 1999. Policy processes within the african national congress and the tripartite alliance. Politikon: South African Journal of Political Studies, 26(1): 5-32.

Loh D 2013. Health Insurance in Singapore. Fromhttp://www.myfareview.com/2013/03/health-insurance-in-singapore/. (Retrieved on 4 June, 2013).

Maarse H Lim M K, Crivelli L, Chinitz D, Cheng TM, Okma KG, 2010. Six Countries, Six Health Reform Models? Health Care Reform in Chile, Israel, Singapore, Switzerland, Taiwan, and the Netherlands" Journal of Comparative Policy Analysis, 12(1): 85-89.

Manchikanti L, Hirsch JA 2009. Obama health care for all Americans: Practical implications. From http://workspace.unpan.org/sites linternet/Documents/UNPAN92985.pdf. (Retrieved on 5 June, 2014).

Mayosi BM, Lawn JE, van Niekerk A, Bradshaw D, Karim SSA, Coovadia HM 2009. Health in South Africa: changes and challenges since 2009. The Lancet, 380(9858): 2029-2043.

McIntyre DI, Doherty J, Gilson L 2003. A tale of two visions: the changing fortunes of Social Health Insurance in South Africa. Health Policy Plan. 18 (1): 47-58.

McIntyre DI, Gilson L 2002. Putting equity in health back onto the social policy agenda: experience from South Africa. Social Science \& Medicine, 54(11): 1637-1656.

Midgley J 2001. South Africa: the challenge of social development, International Journal of Social Welfare, 10(4): $267-275$.

$\mathrm{MoH}$ 2011. Ministry of Health, Singapore, State of Health - The Report of the Director of Medical Services 2001. From http://www.moh.gov.sg/mohcorp/hcsystem.aspx?id=102. (Retrieved on 10 April 2011).

$\mathrm{MOH}$ 2013. Ministry of Health Singapore, Healthcare Financing Philosophy. From http://www.moh.gov.sg/content/moh_web /home/costs_and_financing.html. (Retrieved on 24 July 2013).

NDP 2013. National Development Plan 2030. From http://www.info.gov.za/issues/national-development-plan/. (Retrieved on 26 March 2013).

Nevondwe LT, Odeku KO 2014. Financing the National Health Insurance Scheme of South Africa: Opportunities and Challenges. Journal of Social Sciences 39(1) 9-18. 
NHI 2011. National Health Insurance green Paper 2011. From http://www.hst.org.za/sites/default/files /2bcce61d2d1b8d972af41ab0e2c8a4ab.pdf. (Retrieved on 31 August 2014).

Oberlander J 2010. Long time coming: why health reform finally passed. Health Affairs, 29 (6): 1112-1116.

Okma KGH, Cheng T, Chinitz D, Crivelli L, Lim M, Maarse H, Labra ME 2010. Six Countries, Six Health Reform Models? Health Care Reform in Chile, Israel, Singapore, Switzerland, Taiwan and The Netherlands. Journal of Comparative Policy Analysis: Research and Practice. 12(1-2): 75-113.

PASA 2012. Political Analysis South Africa, Is South Africa's New Growth Path capable of creating jobs? From http://www.politicalanalysis.co.za/2012/09/28/is-south-africas-new-growth-path-capable-of-creating-jobs/. (Retrieved on 26 March 2013).

Phua KH 1997. Medical Savings Accounts and Health Care Financing in Singapore: Innovations in Health Care Financing. From http://books.google.co.za/books?hl=en\&lr=\&id=bdil8bdjxe0c\&oi=fnd\&pg=pa247\& =jphkata6yj\&sig=blfnnecop9aowfhikjsopfkttn0. (Retrieved on 20 March 2013).

RDP 2010. The core values of the RDP. From http://www.anc.org.za/ancdocs/discussion/rdp.html. (Retrieved on 15 April 2010).

Seekings J 2013. Democracy, Poverty and Inclusive Growth in South Africa since 1994. From http://www.cssr.uct.ac.za/sites /cssr.uct.ac.za/files/WP\%20321.pdf. (Retrieved on 15 March, 2014).

Shiou-Liang W, Chok-Kang L, Ganga G et al 2014. Effectiveness of a National Transitional Care program in Reducing acute Care Use. Journal of the American Geriatrics Society, 62(4) 747-753

Shortt S 2002. Medical Savings Accounts in Publicly Funded Health Care Systems: Enthusiasm versus Evidence" Canadian Medical Association Journal, 1:159-161.

Tamiya N, Noguchi H, Nishi A, Reich MR, Ikegami N, Hashimoto H, Shibuya K, Kawachi I, Campbell JC 2011. Population ageing and wellbeing: lessons from Japan's long-term care insurance policy, The Lancet, 388(24-30): 1183-1192.

Terreblanche Sj 2003. A History of Inequality in South Africa 1652 to 2002, Pietermaritzburg, South Africa:University of Natal Press.

Van Aardt CJ ,Ligthelm AA and Van Tonder J 2011. A broad review of the new growth path framework with a specific emphasis on the feasibility of its proposed targets. From http://www.unisa.ac.za/contents/faculties/ems/docs/Press413.pdf, (Retrieved on 26 March 2013.

Visser W 2004. Shifting RDP into GEAR." The ANC government's dilemma in providing an equitable system of social security for the "new" South Africa. Fromhttp://sun025.sun.ac.za/portal/page/portal/Arts/Departemente1/geskiedenis/docs/rdp_into_gear.pdf. (Retrieved on 11 January, 2014).

von Eiff W, Massoro Voo TY, Ziegenbein R 2002. Medical savings accounts: a core feature of Singapore's health care system. The European Journal of Health Economics. 3(3): 188-195.

Wax C 2013. South Africa's Health Care System and its aim to achieve universal coverage. From https://oda.hio.no/jspui/handle/10642/1736. (Retrieved on 15 March, 2014).

WHO 2000.The World Health Report 2000 - Health systems. From www.who.int/whr/2000. (Retrieved on 9 April 2011).

Wu Xu and Ramesh M 2014. Market imperfections, government imperfections, and policy mixes: policy innovations in Singapore. Policy Sciences, 47(3) 305-320. 